\title{
Arló nagyközség Macroheterocera-faunájának vizsgálata (Lepidoptera)
}

\author{
VITKÓ TAMÁS ${ }^{1}$ és FINTHA GABRIELLA ${ }^{2 *}$ \\ ${ }^{1} 1157$ Budapest, Nyírpalota út 25. \\ ${ }^{2}$ Eszterházy Károly Egyetem, Természettudományi Kar, Biológiai Intézet, Növénytani és Növényélettani Tanszék, \\ 3300 Eger, Leányka utca 6. \\ *E-mail: fintha.gabriella@uni-eszterhazy.hu
}

Kivonat. A felmérés célja, hogy egy, az éjszakai lepkefaunát tekintve „fehér foltnak” minősülő Tarnavidéki terület adataival hozzájáruljunk a hazai Macroheterocera-fajok előfordulásának és elterjedésének alaposabb megismeréséhez. A kutatási terület egy diverz és mozaikos élöhelykomplex, amely megfelelő életfeltételeket biztosít számos eltérő igényü lepkefaj számára. Kutatásunk során, bizonyos mértékig antropogén hatások alatt álló három fő vegetációtípus találkozásánál elhelyezkedő területen végeztünk felmérést, melynek eredményeképpen ez idáig 206 éjjeli lepkefaj előfordulását tudtuk regisztrálni. A növényzeti viszonyokkal összhangban a silvicol, illetve a quercetalis fajok jelenléte mellett előfordulnak nedves élőhelytípusokhoz kötődő, sok esetben lápi fajok is, mint például a Diachrysia zosimi (HüBNER, 1822). A detektált fajok között 21 védett fajt találunk, ezek között négy, az EU Élőhelyvédelmi Irányelvének II. függelékében szereplő faj is előkerült: Eriogaster catax (LinNAEUS, 1758), Euplagia quadripunctaria (PODA, 1761) illetve a Dioszeghyana schmidtii (DiósZEGHY, 1935) és a Rhyparioides metelkana (LEDERER, 1861), a két utóbbi egyben fokozottan védett státuszú is.

Kulcsszavak: lepkefaunisztika, Heves-Borsodi-dombság, Tarnavidéki Tájvédelmi Körzet, védett fajok

\section{Bevezetés}

A magyar lepkészet immáron több mint két évszázados mozgalmas múltra tekinthet vissza. Ennek köszönhető, hogy mára már a Kárpát-medence, ezen belül a mai Magyarország területének lepkefaunája egyre nagyobb mértékben kikutatott, bár még ennyi idő eltelte után is találkozunk „fehér foltokkal” a térképen, melyek kutatásával jelentősen gyarapíthatjuk a hazai lepkefaunáról rendelkezésre álló ismereteinket (SZABÓKY 2007).

A föváros környéke és a nagyobb hegyvidékek mellett jellemzően az ország azon pontjairól vannak a legrészletesebb ismereteink, ahol erdészeti és mezőgazdasági fénycsapdák müködnek. Ezek a csapdák hosszú éveken, évtizedeken keresztül pontos és nagy mennyiségü adatot szolgáltatnak. Ez az egyik leghatékonyabb módszer a helyi faunaváltozások tendenciájának nyomon követésére, az egyes fajok egyedszámbeli fluktuációjának regisztrálására, és a nagyon alacsony példányszámú fajok kimutatására (SZABÓKY 2007). 
A folyamatosan változó környezeti és klimatikus viszonyok hatására újabb és újabb fajokat figyelhetünk meg hazánkban. Egyre több vándorló faj jelenlétét tapasztalhatjuk, míg más fajok - melyek még fél évszázada gyakoriak voltak - mára erősen megritkultak vagy el is tüntek. Ennek alapján kijelenthetjük, hogy jelenlegi lepkefaunisztikai ismereteink még korántsem tükrözik az egyes fajok valós elterjedési viszonyait, ezért nagy szükség van a jelen munkához hasonló folyamatos faunisztikai kutatásokra (SZABÓKY 2007).

A Heves-Borsodi-dombság és az Upponyi-hegység területén végzett lepkefaunisztikai felmérések során 113 nappali lepkefaj előfordulását mutatták ki. A felmérés 10 védett nappali és két éjjeli lepkefajra fókuszált (VOZÁR \& KOCSIS 2014). A keresett két éjjeli lepkefajt Arló környékén is sikerült megtalálni: az Eriogaster lanestris az Izra-völgyböl, míg az Eriogaster catax a Gyepes-völgy és az Izra-völgy területéről került elő (VOZÁR \& KOCSIS 2014). Átfogó, éjjeli lepkefaunát vizsgáló felmérés a területen eddig nem történt, ezért kutatásunk célja, hogy további adatokkal szolgáljunk a Tarnavidéki Tájvédelmi Körzet területének lepkefaunájához és megismeréséhez.

\section{Anyag és módszer}

\section{Alkalmazott módszerek}

2004 és 2009 között zajló tematikus vizsgálat és azt követő 10 év terepi megfigyeléseinek eredményeként állítottuk össze az aktuálisan kimutatott fajok listáját. A mintavételezések Arló nagyközség belterületén, másodlagos, antropogén hatások alatt álló élöhelyen történtek. Mintavételi módszerek tekintetében a hazai lepkészeti gyakorlatban általánosan elterjedt éjszakai lámpázással, illetve vödörcsapdázással és csalétkezéssel zajlott a gyűjtés, március és október közötti időszakban.

Az éjszakai lámpázás áprilistól szeptemberig havi két alkalommal, március és október hónapokban havonta egy alkalommal történt. Fényforrásaként $125 \mathrm{~W}$ teljesítményü $\mathrm{HgL}$ típusú higanygőzlámpát alkalmaztunk, mely egy 2,5 m magas állványon volt elhelyezve. A fényforrás több száz m-re volt a település környékén levő természetközeli élőhelyektől (4811'01'’É, 20¹5'31'K).

A vödörcsapdák UV fénycsővel szerelt típusát alkalmaztuk kutatásunk során, melyet 12 V-os akkumulátorról müködtetünk.

Az élőhelyeken, a virágokon zseblámpás terepi megfigyeléseket végezve is történtek adatgyüjtések (1. ábra).

Az egyes gyüjtések adatait minden esetben terepi gyüjtőnaplóban rögzítettük. A fényre repült lepkék közül a faunisztikai jelentőséggel bíró fajok példányai begyüjtésre és preparálásra kerültek. A bizonyító példányok VITKÓ TAMÁS magángyüjteményében találhatóak meg. A területen további mintavételezéseket tervezünk, melynek során kutatásunkat kiterjesztjük az Idaea- és Eupithecia-fajokra is.

Az előkerült fajok meghatározásához VARGA (1989), VARGA et al. (2004), műveit alkalmaztuk, a taxonómiai besorolás és nevezéktan VARGA (2012) és PASTORÁLIS et al. (2016) munkáját követi. A fajok faunatípus és faunakomponens szerinti besorolását 
VARGA et al. (2004) munkája alapján végeztük el. A fajok természetvédelmi státuszát a 13/2001. (V.9.) KöM rendelet alapján állapítottuk meg. A növények elnevezése és határozása KIRÁLY et al. (2008) és KIRÁLY (2009), a társulások elnevezése BORHIDI (2003) munkája alapján történt.

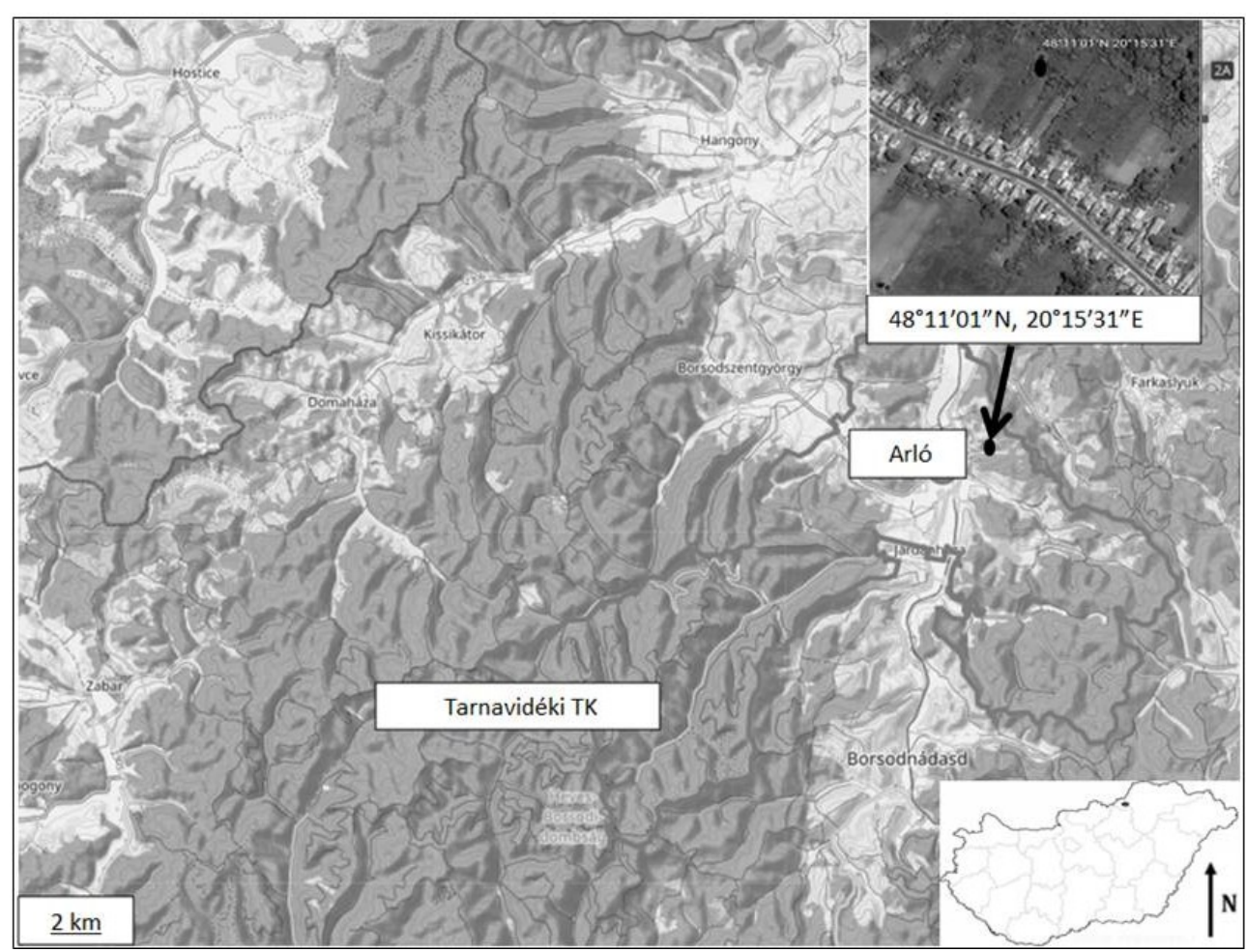

1. ábra. Fénycsapda mintavételi lokalitása, GPS-koordináta: $48^{\circ} 11^{\prime} 01^{\prime \prime} \mathrm{N}, 20^{\circ} 15^{\prime} 311^{\prime \prime} \mathrm{E}$ (forrás: http://web.okir.hu)

Figure 1. Sampling locality, GPS coordinates: $48^{\circ} 11^{\prime} 01^{\prime N} \mathrm{~N}, 2^{\circ} 15^{\prime} 31^{\prime \prime E}$ (source: http://web.okir.hu)

\section{A vizsgálati terület jellemzése}

Az Upponyi-hegység kistájhoz tartozó, Heves-Borsodi-dombság keleti részén, BorsodAbaúj-Zemplén megyében, Ózd-Hódoscsépány mellett Ny-i irányban 6 km-re helyezkedik el Arló nagyközség, amely a Tarnavidéki Tájvédelmi Körzet részét képezi, így a terület a Bükki Nemzeti Park Igazgatóság müködési területe alá tartozik.

A mintegy 1980 hektáros területet két részre osztja a Gyepes- és Palina-völgy közti 360-470 méter magas gerinceken, hegytetőkön húzódó vízválasztó. Alacsony hegyvidéki jellegü kistáj, tengerszint feletti magassága 200-530 méterig (Vajdavár-csoport) terjed. Különböző szintű dombok, ill. hegyormok jellemzik, a tetőkről a völgyekbe helyenként 30-45-os szögben szakadnak le a hegyoldalak, nagy reliefet kölcsönözve a tájnak. 
Éghajlata mérsékelten hűvös-mérsékelten száraz, de az északi futású völgyekben és a magasabb fekvésü katlanokban hűvös-mérsékelten száraz az éghajlat. A mezo- és mikroklimatikus viszonyok az eltérő kitettség, a különböző növénytársulások borítottságés szerkezetbeli eltérései miatt nagyon differenciáltak. A területen nagyrészt rozsdabarna erdőtalaj alakult ki, de agyagbemosódásos és Ramman-féle barna erdőtalaj, földes kopárok, réti és láptalajok is előfordulnak (BARTHA 1996).

Arló és környéke vízrajzának meghatározó tényezői a Hódos-patak, és a suvadással elgátolt, 6 hektár kiterjedésü Arlói-tó (DÖVÉNYI 2010). A Gyepes-völgyben hat, a Palinavölgy Arlóhoz tartozó részén hét állandó és több időszakos müködésű forrás található. Ezeknek meghatározó szerepe van a Gyepes- és Szentgyörgyi-patak, ill. a Gyepes-völgy kisvizeinek vízszint-stabilizálásában, mocsár- és láprétjeinek fenntartásában. A terület sürü és egységes vízhálózata ökológiai szerepénél fogva védelmet érdemel (BARTHA 1996).

\section{A terület növénytársulástani jellemzöi}

A kistáj növényföldrajzi beosztás szempontjából a Pannóniai flóratartomány (Pannonicum) Északi-középhegység flóravidékének (Matricum) Borsodense flórajárásába tartozik.

A túlnyomórészt erdővel fedett kistájon még ma is döntőek a természetes társulások. A térség potenciális erdőtársulásai a szubmontán égerligetek közül a patakparti égerligetek (Alnenion glutinosae-incanae), málló és kilúgozódó homokkövön több helyütt savanyú talaj alakult ki, emiatt mészkerülö erdőfoltok is megjelentek, mint például a mészkerülö gyertyános tölgyesek (Luzulo-Carpinetum). Az északi kitettségü lejtőkön és a mélyebb völgyekben viszonylag nagy kiterjedésű területen jellemzőek a szubmontán bükkösök (Melittio-Fagetum). Zonális fás társulásként legelterjedtebb az alacsonyabb lejtőket illetve a szük völgyszakaszokat övezö - 350-400 méternél magasabb - hegyormok és gerincek tetejét összefüggően borító középhegységi cseres-tölgyesek (Quercetum petraeae-cerredis). A tölgyes és bükkös zóna közti, csak helyenként meglévő sávban hegyvidéki gyertyánostölgyesek (Carici pilosae-Carpinetum) figyelhetők meg felemáslevelü csenkesszel (Festuca heterophylla Lam.), egyvirágú gyöngyperjével (Melica uniflora Retz.) és ligeti perjével (Poa nemoralis L.).

Az erdőssztyepp fajokkal tarkított gyepszintre magas diverzitás jellemző. Megtalálható itt az erdei szamóca (Fragaria vesca L.), erdei gyömbérgyökér (Geum urbanum L.), fehér pimpó (Potentilla alba L.), festő rekettye (Genista ovata W. et K.), érdes csüdfü (Astragalus asper JACQ.), borsóka és vitézi bükköny (Vicia pisiformis L., V. cassubica L.), piros gólyaorr (Geranium sanguineum L.), farkaskutyatej (Euphorbia cyparissias L.), közönséges méreggyilok (Vincetoxicum hirundinaria Medik.), nagyvirágú méhfü (Melittis melissophyllum subsp. carpatica L.), orvosi bakfü (Betonica officinalis L.), közönséges borsfü (Clinopodium vulgare L.), közönséges szurokfü (Origanum vulgare L.), osztrák ökörfarkkóró (Verbascum chaixii subsp. austriacum HAYEK), ösztörüs veronika (Veronica chamaedrys L.), sárga gyüszüvirág (Digitalis grandiflora MILL.), közönséges orbáncfü (Hypericum perforatum L.), sátoros margitvirág (Tanacetum corymbosum SCH. BIP.), bársonyos kakukkszegfü (Lychnis coronaria Desr.), karcsú fényperje (Koeleria cristata PERS. em. BORBÁS ex DOMIN), őszi vérfü (Sanguisorba officinalis L.), habszegfüfélék (Silene spp.). 
A meredek, déli kitettségü lejtők száraz tölgyeseinek cserjeszintjében a szubmediterrán elterjedésü, sárga virágú pukkanó dudafürt (Colutea arborescens L.), valamint a legszebb tarka nőszirom- (Iris variegata L.) és fehér madársisak- (Cephalanthera damasonium DRUCE) állományok is megjelennek.

A vízfolyások mentén mocsárrétekkel, magaskórós társulásokkal, és kaszálórétekkel (Molinio-Arrhenatheretea) tarkított puhafás ligeterdőket (Saliceto-Populeum) összefüggö nádasokat figyelhetünk meg a tó környékén, valamint bokorfüzesek (Salicetea purpureae) maradványfoltjait a Hódos-patak mentén.

A kivágott természetes erdő területeket telepített erdei fenyvesekkel vegyes lucosok (Pinetum sylvestris-Piceetum cultum) és akácos kultúrerdők (Robinetea) váltották fel. E tájidegen fákból álló monokultúrák alatt az aljnövényzet megváltozott, felbukkantak és tömegessé váltak bennük a zavarásra utaló, jobbára ember által behurcolt növények: ragadós galaj (Galium aparine L.), földi és fekete bodza (Sambucus ebulus L., S. nigra L.), nagy csalán (Urtica dioica L.), siska nádtippan (Calamagrostis epigeios RoTH.).

A kutatási terület egy diverz és mozaikos élöhelykomplex, amely láthatóan kiváló életfeltételeket biztosít az itt élő lepkefajok számára.

\section{Eredmények és értékelésük}

1. táblázat. Arló területén detektált védett Macroheterocera-fajok.

Table 1. Protected Macroheterocera species in Arló.

\begin{tabular}{|c|c|c|}
\hline Fajnév & Védett faj eszmei értéke $(\mathrm{Ft})$ & Natura 2000 jelölö \\
\hline Acherontia atropos (LINNAEUS, 1758) & 10000 & \\
\hline Aglia tau (LINNAEUS, 1758) & 5000 & \\
\hline Autographa bractea ([D. \& SCH.], 1775) & 10000 & \\
\hline Diachrysia chryson (ESPER, 1789) & 50000 & \\
\hline Diachrysia zosimi (HÜBNER, 1822) & 50000 & \\
\hline Dioszeghyana schmidtii(DIÓSZEGHY, 1935) & 100000 & II. és IV. melléklet \\
\hline Endromis versicolora (LINNAEUS, 1758) & 5000 & \\
\hline Eriogaster catax (LINNAEUS, 1758) & 50000 & II. és IV. melléklet \\
\hline Eriogaster lanestris (LINNAEUS, 1758) & 10000 & \\
\hline Euplagia quadripunctaria(PODA, 1761) & 5000 & II. melléklet \\
\hline Hydria undulata (LINNAEUS, 1758) & 5000 & \\
\hline Hyles gallii(ROTTEMBURG, 1775) & 5000 & \\
\hline Lycophotia porphyrea ([D. \& SCH.], 1775) & 10000 & \\
\hline Marumba quercus (LINNAEUS, 1758) & 10000 & \\
\hline Ocneria rubea ([D. \& ScH.], 1775) & 10000 & \\
\hline Phalera bucephaloides(OCHSENHEIMER, 1810) & 10000 & \\
\hline Rhyparioides metelkana(LEDERER, 1861) & 250000 & II. melléklet \\
\hline Saturnia pyri ([D.\& ScH.], 1775) & 50000 & \\
\hline Saturnia pavoniella $(\mathrm{SCOPOLI}, 1763)$ & 10000 & \\
\hline Scotochrosta pulla ([D. \& SCH.], 1775) & 5000 & \\
\hline Tyria jacobaeae (LINNAEUS, 1758) & 5000 & \\
\hline
\end{tabular}


A vizsgálatok során 206 faj került azonosításra (Melléklet), amelyek közül több faj is természetvédelmi jelentőséggel bír. A védett fajok száma 21 (1. táblázat), amelyek között négy az EU Élőhelyvédelmi Irányelvének II. függelékében szerepel: Eriogaster catax (LINNAEUS, 1758), Euplagia quadripunctaria (PODA, 1761) illetve a Dioszeghyana schmidtii (DIÓSZEGHY, 1935) és a Rhyparioides metelkana (LEDERER, 1861), a két utóbbi egyben fokozottan védett státuszú is.

A kutatási területen előforduló természetvédelmi és/vagy faunisztikai szempontból jelentősebb fajok:

\section{Acherontia atropos (LINNAEUS, 1758)}

Klasszikus mediterrán vonuló faj. Trópusi Afrikában és Ázsia délnyugati részén honos, Magyarországra (és tőlünk északabbra) csak vándorlásai során jut el. Gyakoriságának ingadozása valószínúleg a klímaperiódusok változásával is összefügg, de minden bizonnyal a nagyüzemi burgonyaföldek erősebb vegyszerezésével is kapcsolatba hozható. Hazai előfordulása megritkult.

Megjegyzés: a területről általában évente csak egyszer volt észlelhető fénycsapdázások alkalmával.

Védett faj.

Aglia tau (LInNAeUS, 1758)

Magyarországon gyakori a hegyvidéki bükkösökben és rendszeresen előforduló faj a dombvidékek kocsánytalan tölgyeseiben. A hímek nappal is, míg a nőstények éjszaka repülnek. Jellemző tápnövényük a Fagus sylvatica L.

Megjegyzés: több tavaszi lámpázáson is megfigyelhető volt néhány nőstény példány.

Védett faj.

Anaplectoides prasina ([DENIS \& SCHIFFERMÜLLER], 1775)

Magyarországon a Középhegységben gyakori fajnak számít. Zonális erdősztyepp és hegyvidéki lombhullató erdőkben jelenik meg. Jellemzően júniustól augusztus végéig repül.

Megjegyzés: csalétken és vödörcsapdában is elöfordult.

Nem védett faj.

Autographa bractea ([DENIS \& SCHIFFERMÜLLER], 1775)

Jellegzetes hegyvidéki faj, üde hegyvidéki réteken, tisztásokon, patak mentén él. Hazánk egyik legnagyobb aranybaglya. Élőhelyén nem ritka, de soha sem tömeges.

Megjegyzés: a faj a jellemző repülési idejében 1-2 példánnyal jelent meg a fényforrásunknál több alkalommal.

Védett faj. 
Autographa pulchrina (HAWORTH, 1809)

Jellegzetesen hegyvidéki, nedves élőhelyeket kedvelő faj, amely különböző lágyszárúakat fogyaszt.

Megjegyzés: a területről vödörcsapdázás és lámpázás során is előkerült.

Nem védett faj.

Cerapteryx graminis (LINNAEUS, 1758)

Nyílt gyepes területeket kedvelö faj, amely nappal és éjszaka is mutat aktivitást. Az 1970-es években történt átmeneti szétterjedése után magasabb hegységeinkbe húzódott vissza, és manapság is inkább csak ilyen vidékeken található. Előfordulása a mintavételi területen annak viszonylag alacsony tengerszint feletti magassága miatt figyelemre méltó.

Megjegyzés: fénycsapdázásokon jelent meg példánya.

Nem védett faj.

Cyclophora albiocellaria (HÜBNER, 1789)

Hazánkban országszerte megfigyelt faj, jellemzően alacsony egyedszámmal fordul elő. Hernyója Aceraceae fajokon él.

Megjegyzés: vödörcsapdázás és lámpázás alkalmával is észlelhető volt.

Nem védett faj.

Diachrysia chryson (ESPER, 1789)

Hegyvidéki faj, hűvös, nedves völgyekben, üde réteken, patakok mentén fordul elő.

Megjegyzés: a területről vödörcsapdázás során került elő.

Védett faj.

Diachrysia zosimi (HÜBNER, 1822)

Ponto-Pannon diszjunkt faunaelem, lápréti faj. Magyarországon szórványosan fordul elö láp- és mocsárréteken, föleg a Dunántúlon, de az Alföld északi és nyugati részén, valamint az Északi-középhegység előterében is észlelték. Egyes élőhelyein óriási egyedszámban (100-200 példány) jelenhet meg a fényen. A Nyírség északi részén és a SzatmárBeregi-síkon általánosan elterjedt és viszonylag gyakori, míg a Tiszántúl többi területén ritka és lokális.

Hernyójának kizárólagos tápnövénye az őszi vérfü (Sanguisorba officinalis).

Megjegyzés: többször is észlelhető volt a fénycsapdázások alkalmával.

Védett faj. 


\section{Dioszeghyana schmidtii (DIÓSZEGHY, 1935)}

Elterjedését lokálisnak mondják és az Acer tataricum-hoz kötötték, de az újabb kutatások szerint nem kizárólag a tatárjuhar a faj jellemző tápnövénye, hanem megjelenése gyakori a csertölgyesekben is. Jelenleg vizsgált területen is gyakoribb növény a Quercus cerris, mint az Acer tataricum.

Megjegyzés: tavaszi lámpázások alkalmával jelent meg.

Vörös Könyvben szereplő, fokozottan védett faj, amely az Élöhelyvédelmi Irányelv II. és IV. mellékletében is szerepel, NATURA 2000-es jelölő faj, amely a Berni Egyezmény hatálya alá tartozik.

\section{Endromis versicolora (LINNAEUS, 1758)}

Hazai megjelenésére föként a nyíres területek, illetve az égerligetek jellemzőek, mert hernyója Betula- és Alnus-fajokon fejlődik. A hímek nappal is aktívak.

Megjegyzés: kora tavaszi időszaktól többször megfigyelhető volt lámpázások alkalmával.

Védett faj.

\section{Eriogaster catax (LINNAEUS, 1758)}

Hernyójának fö tápnövénye közé tartozik a területen is tömegesen elöforduló kökény (Prunus spinosa), a galagonya (Crataegus) és a tölgyfélék (Quercus).

Megjegyzés: a területről maradványai kerültek elö.

Vörös Könyvben szereplö, védett faj, amely az Élőhelyvédelmi Irányelv II. és IV. mellékletében is szerepel, NATURA 2000-es jelölő faj, amely a Berni Egyezmény hatálya alá tartozik, illetve NBMR Programban szereplö taxon.

\section{Eriogaster lanestris (LINNAEUS, 1758)}

A területen gyakori galagonya (Crataegus) és kökény (Prunus spinosa) hernyójának fö tápnövénye.

Megjegyzés: hernyófészekben volt megfigyelhető a vizsgálati területen.

Védett faj.

\section{Euplagia quadripunctaria (PODA, 1761)}

Hernyója polifág, leginkább az üde erdők lágyszárú növényzetét fogyasztja, gyakran Lamium-, Urtica-fajokon él, de kifejlődik Prunus- és Quercus-fajokon is. Hazánkban a Dunántúlon és a Középhegységben gyakori.

Megjegyzés: vödörcsapda fényforrása körül illetve lápmázáson volt megfigyelhető nyár végi időszakban.

Védett faj, amely az Élőhelyvédelmi Irányelv II. mellékletében is szerepelő NATURA 2000-es jelölö faj. 


\section{Hadena magnolii (BOISDUVAL, 1829)}

Magyarországon lokális és általában ritka. Elsősorban domboldalak homokgyepeiben, löszgyepekben, ritkábban sziklagyepeknél találkozhatunk a fajjal. A mesterséges fény vonzza, mivel csalétekre repülő példányról eddig nincs információnk, így vélhetőleg közömbös rá.

Megjegyzés: mint minden Hadena sp., ez a faj is viráglátogató, tevékenységét már a szürkületi órákban elkezdi, így zseblámpával való keresése a virágoknál táplálkozó lepkéknek igen eredményes volt.

Nem védett faj.

\section{Hydria undulata (LINNAEUS, 1758)}

Magyarországon a leginkább az északkeleti hegyvidékeken fordul elő, keményfaligeterdei és szurdokerdei faj. Az ismert élöhelyeken is kis egyedszámban észlelhető. Lárvájának jellemző tápnövénye Fraxinus-, illetve Salix-fajok.

Megjegyzés: a fényforrásokon gyakran megjelenő faj.

Védett faj.

\section{Hyles gallii (ROTTEMBURG, 1775)}

Lápréti faj, réteken, nedves erdei területeken és ligetes helyeken fordul elő. Hernyójának tápnövénye különböző lágyszárúak, de legfőképpen a Galium-fajok. Az őszi bábok a talajban telelnek át.

Megjegyzés: lámpázáson többször megjelent.

Védett faj.

Hyles livornica (ESPER, 1780)

Hazánkban igen ritka. Előfordul, hogy a vándorlásai során évekig nem érintik hazánk területét. Polifág, lágyszárúakon és cserjéken is élhet.

Megjegyzés: a területen megfigyelhető volt csalétken és fénycsapdán is.

Nem védett faj.

\section{Lycophotia porphyrea ([DENIS \& SCHIFFERMÜLLER], 1775)}

Hazánkban szórványosan előforduló, kifejezetten lokálisnak nevezhető faj. A tápnövényeként szolgáló Calluna vulgaris és Erica spp. termőhelyeit ritkán hagyja el.

Megjegyzés: korai őszi időszakban volt észlelhető néhány alkalommal a fényforrás körül egy-egy példánya.

Védett faj. 


\section{Marumba quercus (LINNAEUS, 1758)}

Hazánkban domb- és hegyvidékeken fordul elő. Száraz meleg tölgyeseket kedveli. Jelenléte idősebb, meleg, jó állományú tölgyerdőt jelez, molyhos-tölgyesek karakterfaja. A mesterséges fény, különösen a higanygőzlámpák fénye erősen vonzza. Lárvája elsősorban a molyhos tölgyön (Quercus pubescens) található, de elöfordul a cser- és a kocsánytalan tölgyön (Quercus cerris, Q. petraea) is.

Megjegyzés: ez a faj lámpázáson és vödörcsapdán sem volt megfigyelhető, de maradványai előkerültek a présház épületéből.

Védett faj. Vörös Könyvben szereplő faj.

\section{Ocneria rubea ([DENIS \& SCHIFFERMÜLLER], 1775)}

Magyarországon, a Dunántúli területeken, illetve az Északi-középhegységben fordul elö szórványosan. Tápnövénye a Quercus pubescens, mely a vizsgálati területen jellemző.

Megjegyzés: nyári időszakokban jött a fényforrásokra.

Védett faj.

\section{Phalera bucephaloides (OCHSENHEIMER, 1810)}

Ponto-mediterrán faunaelem, pubescentális (molyhos-tölgyes) faj. Hazánkban egyedszáma mindenütt alacsony. Fő élőhelyei karsztbokorerdők, de olykor más, meleg dombtetői tölgyesekben is megtalálható. Hernyójának tápnövényei különbözö tölgy-félék (Quercus spp.), föleg molyhos tölgy (Q. pubescens).

Megjegyzés: a faj a fénycsapdázások alkalmával többször előkerült.

Védett, Vörös Könyvben szereplő faj.

\section{Rhyparioides metelkana (LEDERER, 1861)}

Hazánk állatföldrajzi szempontból egyik legjelentősebb természeti értékének tekinthető faj. Európa szerte szaggatott elterjedésű, diszjunkt faunaelem. Hernyója mocsári növényeken él, gyakran úszva közelíti meg a tápnövényt. Leggyakrabban Caltha palustris-t és Euphorbia palustris-t fogyaszt, de kedvel egyéb nedves területeken élő lágyszárúakat is.

Megjegyzés: nyári lámpázásokon került elö.

Fokozottan védett, Vörös Könyvben szereplö faj. Az Élöhelyvédelmi Irányelv II. mellékletében is szerepel.

\section{Saturnia pyri ([DENIS \& SCHIFFERMÜLLER], 1775)}

Hazánkban országszerte előfordul, helyenként gyakori, elsősorban olyan erdőkben honos, ahol elegyfafajként gyümölcsfák is vannak.

Megjegyzés: a faj vödörcsapdára és lámpázásra sem jött, de maradványai megtalálhatóak voltak a présház épületében.

Védett faj. 
Saturnia pavoniella (SCOPOLI, 1763)

Hazánkban sokfelé elterjedt, gyakori faj. A vizsgálati területen több tápnövénye is megtalálható: Prunus spinosa, Rubus-, Fragaria-, Sambucus-, Crataegus-, Quercus-, Populus-, Betula-, Salix-, Malus- és Sorbus fajok.

A hímek nappal, a nőstények este repülnek.

Megjegyzés: kora tavasszal volt gyakran észlelhető a fényforrások körül.

Védett faj.

\section{Scotochrosta pulla ([DENIS \& SCHIFFERMÜLLER], 1775)}

Élőhelyei meleg, száraz bokorerdők, mészkő- és dolomit-sziklagyepek, sziklás felszínü ritkás tölgyesek. Tápnövényei Quercus-fajok. Nem gyakori.

Megjegyzés: a fény és a csalétek erősen vonzza, általában késő éjjel jelentkezett a fényforrásnál, a csaléteknél kicsit hamarabb.

Védett faj.

Tyria jacobaeae (LINNAEUS, 1758)

Magyarországon szélesen elterjedt faj, mely a késő éjjeli órákban jelenik meg, időnként nappali aktivitása is észlelhető. Dombvidéki száraz gyepekben előforduló Senecio-fajokon él meg.

Megjegyzés: ritkán észlelhető volt a fényforrások körül.

Védett faj.

\section{A vizsgált terület Macroheterocera-faunájának jellemzése}

A felmérés során összesen 206 faj került azonosításra a vizsgált Arló környéki területröl. A fajok 11 családból és 27 alcsaládból kerültek ki, ezek közül a területen a legnagyobb fajszámot prezentáló családok a Noctuidae (79), a Geometridae (44) és az Erebidae (35) (2. ábra). A lepkecsaládok hazai össz-fajszámaihoz viszonyítva, a vizsgálati területen azon családok észlelési aránya magas, amelyek tagjai nagyobb termetủek és jobb röpképességüek, tehát könnyebben juthattak el távolabbi élőhelyekröl is a mintavétel helyszínére: Sphingidae (65\%), Lasiocampidae (40\%), Noctuidae (38,5\%).

Az arlói faunában jellemző Noctuidae és a Geometridae családok magas fajszáma az egyébként is magas hazai fajszámmal magyarázható.

Élőhelyigényeik alapján a transzpalearktikus fajok tekinthetők a legváltozatosabbnak, így ök vannak jelen a területen a legmagasabb arányban (70\%). Mindösszesen három délikontinentális faj jelent meg a vizsgálat során, amelyek mindegyike lápréti faunakomponensekhez kötődő taxon: Diachrysia zosimi, Eucarta amethystina, E. virgo (3. ábra).

A terület növényzeti adottságait figyelembe véve, illetve hogy a mintavételek másodlagos, antropogén hatások alatt álló területen történtek, nem meglepő, hogy a több tényezőre nézve tágtürésü euryök fajok képviseltették magukat legnagyobb számban (50) a vizsgált terület faunájában (4. ábra). 


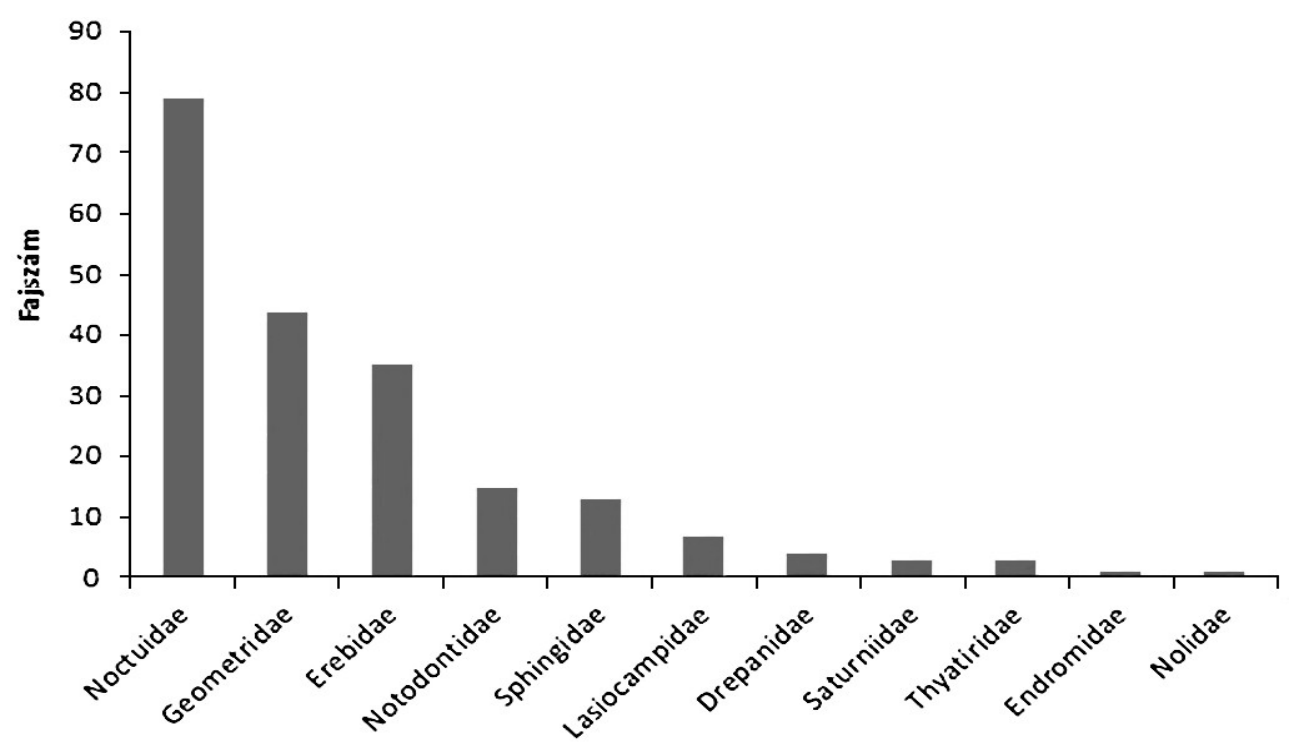

2. ábra. A detektált fajok rendszertani megoszlása

Figure 2. Taxonomic distribution of the detected species

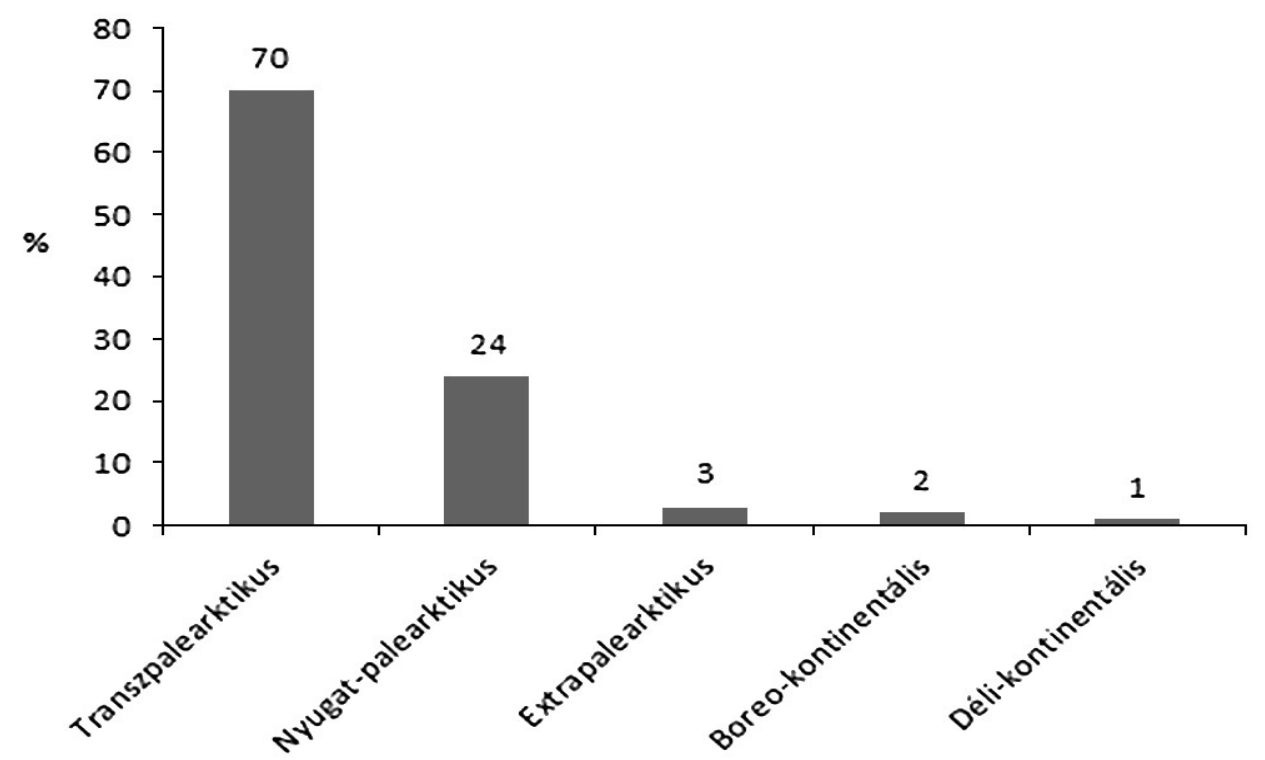

3. ábra. A detektált fajok faunatípus szerinti megoszlása

Figure 3. Distribution of the species occurring in the study area according to faunal types 


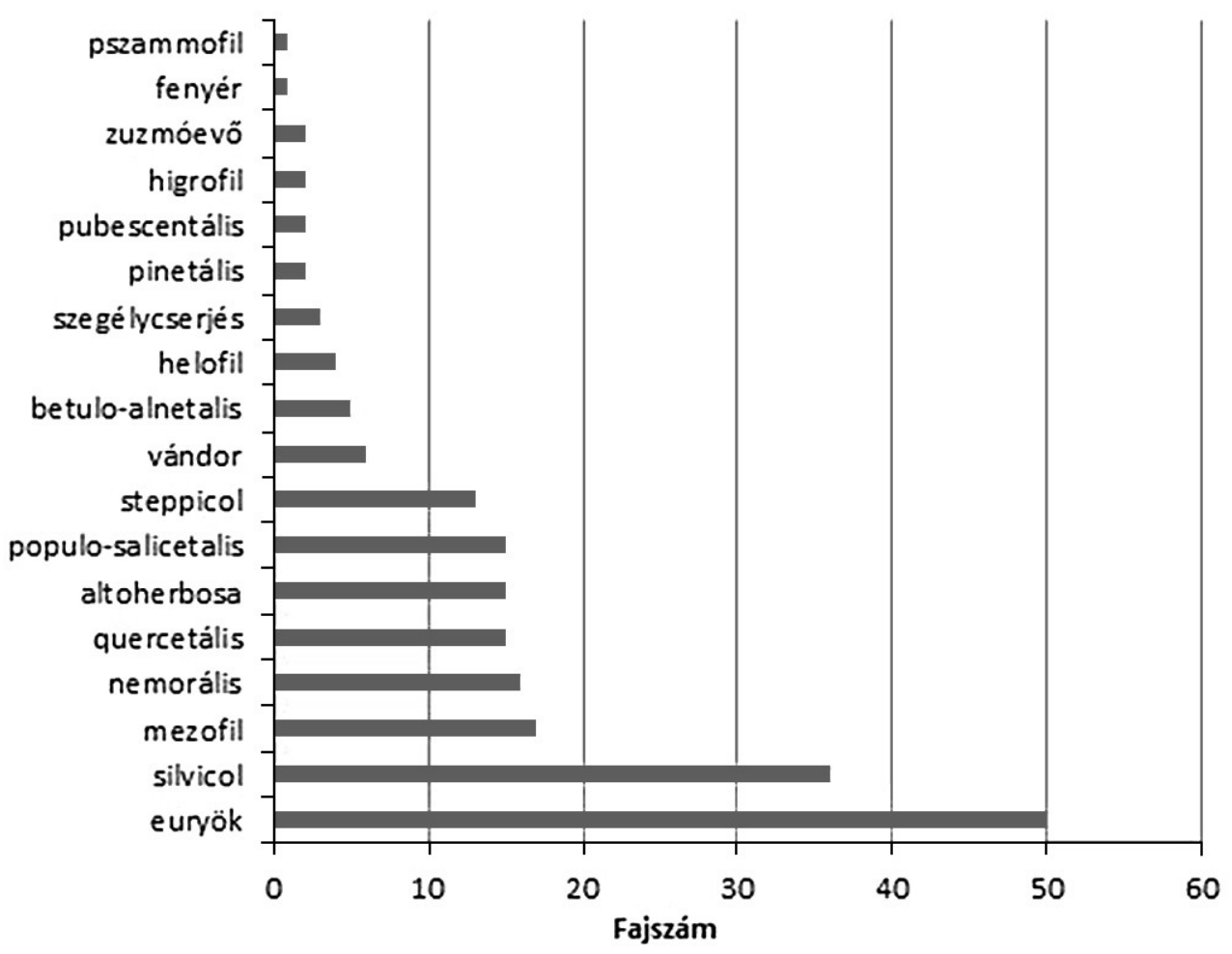

4. ábra. A vizsgált területen előforduló fajok ökológiai igény szerinti megoszlása

Figure 4. Distribution of the species occurring in the study area according to ecological demand

A növényzeti viszonyokkal összhangban az arboreális faunakomponensekhez köthető az általános lomberdei (silvicol), az üde lomberdei (nemorális), illetve a tölgyeseket kedvelő (quercetális) fajok jelentős számban vannak jelen az arlói faunában (5. ábra).

Nedvesebb gyeptársulások a Hódos-patak menti területeken találhatóak, ezek közelségét jelzik a mintavételi helyen megfigyelt magaskórós élőhelyekhez kötődő (altoherbosa) szórványos előfordulású fajok, amelyek természetvédelmi és faunisztikai szempontból kiemelkedő eredmények: Autographa bractea, A. pulchrina, Diachrysia chryson.

Ugyanakkor a szárazabb, fajgazdag kakukkfüves sztyepprétek fajai is elökerültek a lámpázások során: Watsonarctia deserta, Gonospileia triquetra, Cucullia fraudatrix, Hadena magnolii. 


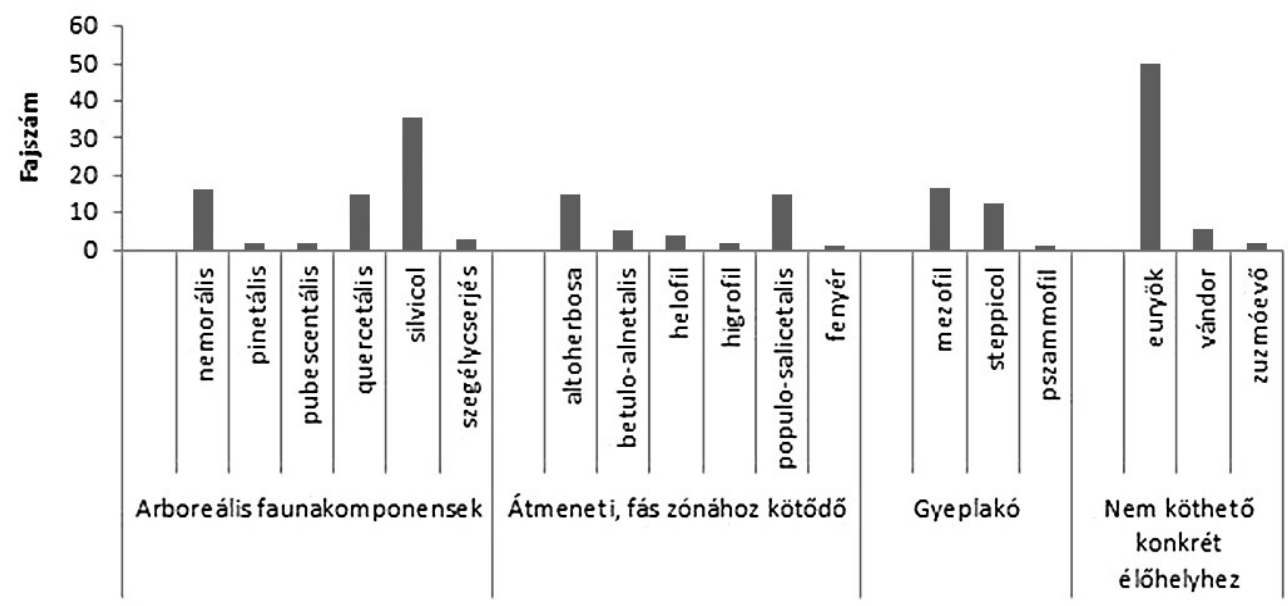

5. ábra. A vizsgált területen előforduló fajok faunakomponens szerinti megoszlása

Figure 5. Distribution of the species occurring in the study area according to faunal components

Nagyobb számban jelentek meg a molyhos tölgyesekhez kötődő természetvédelmi szempontból jelentős fajok: Phalera bucephaloides, Scotochrosta pulla, amelyek az Arló környéki xerotherm tölgyesek természetközeli állapotát jelzik.

A nyáras-füzes fajok, mint a Laothoe populi, a Tethea or és a Pheosia tremula magas részesedési aránya a Hódos-patak mentén található maradvány puhafás ligeterdők közelségével magyarázható.

Az üde lomberdők már nagyrészt áldozatul estek a vidékre jellemző fatolvajlásnak, így az ezekhez kötődő nemorális elemek aránya is jóval alacsonyabb, mint akár 10-20 évvel ezelött lehetett.

Mivel a lepkéknek viszonylagosan nagyobb távolságot kellett megtenni az élöhelyüktől, míg eljutottak a lámpához, ezért a jó repülő vándor fajok nagyobb eséllyel érték el a fényforrást: Agrius convolvuli, Hyles euphorbiae, Hyles gallii amelyek között faunisztikai érdekességnek számít az Acherontia atropos, a Hyles livornica és nem utolsósorban a Mythimna unipuncta.

A jelen tanulmányban közölt 206 faj közel 20\%-át teszi ki a hazai Macroheterocerafaunának. A felmérés során előfordult olyan mintavételi alkalom, amelynek során több mint 100 faj megfigyelésére volt lehetőség, ez is a területre jellemző élőhely-diverzitásnak köszönhető, hiszen eltérö ökológiai igényü fajok jól reprezentálják a vizsgált terület mozaikosságát.

\section{A terület Lepidoptera faunáját veszélyeztetö tényezök}

A különböző területekre jellemző lepkefauna teljes feltárása, feltérképezése lehetetlen, hiszen egy terület faunája nem tekinthető statikus állapotúnak, amelynek összetett okai között szerepel egyrészt az élőhelytípusok dinamikus módosulása, másrészt az egyes fajok adaptációs képességének változása. A természetes folyamatokon túl az antropogén hatások 
következtében tapasztalható klímaváltozás is jelentős átalakulást eredményezhet egy fauna fajösszetételében.

Jelen kutatás során is megfigyelhetőek voltak vándorlepkék, a gyakori Noctua-fajokon kívül, rendszeresen észlelhető a területen a Hyles livornica és az Acherontia atropos, amelyek megjelenése klimatikus változásokra enged következtetni.

A vizsgált terület lepkefaunáját aktuálisan veszélyeztető tényezők közül kiemelendő a rendszeres fatolvajlás, mely komoly degradáló tényező a lepkefauna élőhelyének tekintetében, illetve a rendszeres legeltetés megszünésével észlelhető gyepzáródás, amelynek eredményeként a természetes gyepvegetáció diverzitása folyamatosan csökken, így az ott élő fauna számára optimális tápnövények eltünnek, visszaszorulnak és ez kikerülhetetlen változásokat eredményez a terület aktuális Lepidoptera-fajösszetételében.

Köszönetnyilvánítás. A szerzök köszönettel tartoznak Ronkay Lászlónak a kézirat átnézéséért és a taxonómiai korrekcióért, Kiss Ádámnak és Tóth Balázsnak a szakszerü lektorálásért és hasznos útmutatásokért, az első szerző köszönetet mond Varga Zoltán Professzor úrnak és Korompai Tamásnak a határozásban nyújtott segítségért.

\section{Irodalomjegyzék}

BARTHA Cs. 1996. Arló nagyközség nyugati részének természeti értékei. KTM kutatási jelentés, Budapest.

BÁLINT Zs., PitTer G. \& GuBÁNYI A. 2006. Magyarország védett pillangóalakú lepkéinek katalógusa a Magyar Természettudományi Múzeum gyüjteményei alapján. Magyar Természettudományi Múzeum, Budapest, $136 \mathrm{pp}$.

BoRHIDI A. 2003. Magyarország növénytársulásai. Akadémiai Kiadó, Budapest, 610 pp.

DöVÉNYI Z. (szerk.) 2010. Magyarország kistájainak katasztere. MTA Földrajztudományi Kutatóintézet, Budapest, 824 pp.

LAFRANCHIS T. 2007. Butterflies of Europe. New Field Guide and Key. Diatheo, Paris, 351 pp.

KIRÁly G., MolnÁR Zs., BÖlÖNI J., CsIKY J. \& VoJTKÓ A. 2008. Magyarország földrajzi kistájainak növényzete. MTA ÖBKI, Vácrátót, 248 pp.

KIRÁLY G. (szerk.) 2009. Új Magyar Füvészkönyv. Magyarország hajtásos növényei. Határozókulcsok. Aggteleki Nemzeti Park Igazgatóság, Jósvafó, 616 pp.

Pastorális G., Buschmann F. \& RonKay L. 2016. Magyaroroszág lepkéinek névjegyzéke. e-Acta Naturalia Pannonica 12: 1-262.

SzABÓKy Cs. 2007. A lepkészet története Magyarországon. Magánkiadás, Budapest, 416 pp.

VARGA Z. 1989. Lepkék (Lepidoptera) rendje. In: RonKAY L. (szerk.) Vörös Könyv. Akadémiai Kiadó, Budapest, pp. 188-244.

VARga Z., RonkAy L., BÁlint Zs., LÁszló M. Gy. \& Peregovits L. 2004. A magyar állatvilág fajjegyzéke. 3. kötet. Nagylepkék. Magyar Természettudományi Múzeum, Budapest, 108 pp.

VARGA Z. (szerk.) 2012. Magyarország nagylepkéi (Macrolepidoptera of Hungary). Heterocera Press, Budapest, $253 \mathrm{pp}$. 
VozÁR Á. \& Kocsis M. 2014. Védett lepkefajok előfordulásai, állományai a Heves-Borsodi-dombság és az Upponyi-hegység területén. In: DiczHÁzi I. \& SchMOTZER A. (szerk.) APOKA A HevesBorsodi-dombság és az Upponyi-hegység élővilága. Bükki Nemzeti Park Igazgatóság, Eger, pp. $105-122$.

13/2001. (V. 9.) KöM-rendelet a védett és a fokozottan védett növény-és állatfajokról, a fokozottan védett barlangok köréröl, valamint az Európai Közösségben természetvédelmi szempontból jelentös növény- és állatfajok közzétételéröl. https://net.jogtar.hu/jogszabaly?docid=a0100013.kom (utolsó megtekintés 2021. szept. 17.) 


\section{Melléklet: Arló területén kimutatott nagylepkefajok (Macroheterocera) listája Appendix: List of Macrolepidoptera species recorded in Arló}

Jelmagyarázat: Számokkal jelzett faunatípusok: 0 - Extrapalearktikus; 1 - Transzpalearktikus; 2 Nyugat-palearktikus; 3 - Boreo-kontinentális; 4 - Déli-kontinentális. Betükkel jelzett faunakomponensek: Alto - altoherbosa; Alt-Nem - altoherbosa nemoralis; B-A - betulo-alnetalis; E - euryök; Eer - euryök erdei; E-nye - euryök nyárevö; E-st - euryök steppicol; Fe - fenyér; Helo - helofil; Hig higrofil; Nem - nemoralis; Mezo - mezofil; Mezo-H - mezofil-higrofil; P-S - populo-salicetalis; Pi pinetalis; Pub - pubescentalis; Psz - pszammofil; Q - quercetalis; S - silvicol; S-Esz - silvicolerdőszegély; St - steppicol; St-Rup - steppicol-rupicol; SzCs - szegélycserjés; ZE - zuzmóevő; V vándor

Legend: Faunal types marked with numbers: 0 - Extrapalaearctic; 1 - Transpalaearctic; 2 - West Palaearctic; 3 Boreo-continental; 4 - South-continental. Faunal components marked with letters: Alto - altoherbosa; Alt-Nem altoherbosa nemoralis; B-A - betulo-alnetal; E - euryoecious; E-er - euryoecious woodland species; E-nye euryoecious poplar-feeding; E-st - euryoecious steppicol; Fe - heath; Helo - helophilous; Hig - hygrophilous; Nem - nemoral; Mezo - mesophilous; Mezo-H - mesophilous- hygrophilous; P-S - populo-salicetal; Pi - pinetal Pub - pubescental; Psz - psammophilous; Q - quercetal; S - silvicol; S-Esz - silvicol-woodland edge; St steppicol; St-Rup - steppicol-rupicol; SzCs - hedgerow; ZE - lichenivorous; V - vagrant

\section{Sphingidae}

Smerinthinae

Sphinginae

Macroglossinae

Saturniidae

Syssphinginae

Saturniinae

Drepanidae

Thyatiridae
Laothoe populi (LiNNAEUs, 1758)

Marumba quercus ([DENIS \& SCHIFFERMÜLLER], 1775)

Mimas tiliae (LinNAEUS, 1758)

Smerinthus ocellatus (LinNaEUS, 1758)

Acherontia atropos (LinNAEUS, 1758)

Agrius convolvuli (LiNNAEUS, 1758)

Hyloicus pinastri (LinNAEUS, 1758)

Sphinx ligustri (LinNAEUS, 1758)

Macroglossum stellatarum (LinNAEUs, 1758)

Deilephila elpenor (LinNAEUs, 1758)

Deilephila porcellus (LinNAEUs, 1758)

Hyles euphorbiae (LINNAEUS, 1758)

Hyles gallii (RotTEMBURG, 1775)

Hyles livornica (ESPER, 1780)

Aglia tau (LinNAEUs, 1758)

Saturnia pyri ([DENIS \& SCHIFFERMÜLLER], 1775)

Saturnia pavoniella (SCOPOLI, 1763)

Cilix glaucata (SCOPOLI, 1763)

Drepana curvatula (BORKHAUSEN, 1790)

Falcaria lacertinaria (LINNAEUS, 1758)

Watsonalla binaria (HuFNAGEL, 1767)

Habrosyne pyritoides (HufNAGeL, 1767)

Tethea or ([DENIS \& SCHIFFERMÜLLER], 1775)

Thyatira batis (LINNAEUs, 1758)
E-nye

Q

$\mathrm{S}$

P-S

$\mathrm{V}$

V

Pi

E-er

E-st

Alto

E

$\mathrm{St}$

Mezo

V

Nem

$\mathrm{S}$

SzCs

$\mathrm{S}$

B-A

B-A

Q

E-er

P-S

E-er 


\section{Melléklet (Folytatás) \\ Appendix (Continued)}

\section{Geometridae}

Oenochrominae

Ennominae

Geometrinae

Larentinae

Sterrhinae

\begin{tabular}{|c|c|c|}
\hline Alsophila aescularia ([DENIS \& SCHIFFERMÜLLER], 1775) & 1 & S \\
\hline Abraxas sylvata (SCOPOLI, 1763) & 1 & Nem \\
\hline Agriopis bajaria ([DENIS \& SCHIFFERMÜLLER], 1775) & 2 & Nem-S \\
\hline Agriopis marginaria (FABRICIUS, 1776) & 2 & S \\
\hline Alcis repandata (LINNAEUS, 1758) & 1 & Nem \\
\hline Angerona prunaria (LINNAEUS, 1758) & 1 & E-er \\
\hline Biston betularius (LINNAEUS, 1758) & 1 & E-er \\
\hline Biston stratarius (HuFNAGEL, 1767) & 2 & $\mathrm{~S}$ \\
\hline Campaea margaritaria (LINNAEUs, 1761) & 2 & $\mathrm{~S}$ \\
\hline Colotois pennaria (LINNAEUS, 1761) & 2 & Q \\
\hline Ematurga atomaria (LINNAEUS, 1758) & 1 & $\mathrm{E}$ \\
\hline Ennomos erosaria ([DENIS \& SCHIFFERMÜLLER], 1775) & 2 & Q \\
\hline Heliomata glarearia ([DENIS \& SCHIFFERMÜLLER], 1775) & 2 & St \\
\hline Hypomecis punctinalis (SCOPOLI, 1763) & 1 & $\mathrm{~S}$ \\
\hline Hypomecis roboraria ([DENIS \& SCHIFFERMÜLLER], 1775) & 1 & S \\
\hline Ligdia adustata ([DENIS \& SCHIFFERMÜLLER], 1775) & 2 & $\mathrm{~S}$ \\
\hline Lomaspilis marginata (LINNAEUS, 1758) & 1 & Nem \\
\hline Lomographa bimaculata (FABRICIUS, 1775) & 1 & $\mathrm{~S}$ \\
\hline Macaria alternata ([DENIS \& SCHIFFERMÜLLER], 1775) & 1 & Nem \\
\hline Macaria wauaria (LINNAEUS, 1758) & 1 & Alt-Nem \\
\hline Opisthograptis luteolata (LinNAEUS, 1758) & 1 & $\mathrm{~S}$ \\
\hline Ourapteryx sambucaria (LINNAEUS, 1758) & 1 & Alt \\
\hline Peribatodes rhomboidarius ([DENIS \& SCHIFF.], 1775) & 1 & E-er \\
\hline Plagodis dolabraria (LinNAEUs, 1767) & 1 & $\mathrm{~S}$ \\
\hline Selenia lunularia (HÜBNER, 1788) & 2 & $\mathrm{~S}$ \\
\hline Selenia tetralunaria (HuFNAGEL, 1767) & 1 & Nem \\
\hline Geometra papilionaria (LINNAEUS, 1758) & 1 & $\mathrm{~B}-\mathrm{A}$ \\
\hline Hemistola chrysoprasaria (ESPER, 1795) & 1 & $\mathrm{~S}$ \\
\hline Thalera fimbrialis (SCOPOLI, 1763) & 1 & S \\
\hline Aplocera plagiata (LINNAEUS, 1758) & 1 & $\mathrm{~S}$ \\
\hline Epirrhoe tristata (LINNAEUS, 1758) & 1 & Mezo \\
\hline Hydria undulata (LiNNAEUs, 1758) & 1 & Nem \\
\hline Lithostege griseata ([DENIS \& SCHIFFERMÜLLER], 1775) & 1 & St \\
\hline Lobophora halterata (HUFNAGEL, 1767) & 1 & Nem \\
\hline Scotopteryx chenopodiata (LINNAEUS, 1758) & 2 & Mezo \\
\hline Xanthorhoe ferrugata (CLERCK, 1759) & 1 & E \\
\hline Xanthorhoe fluctuata (LinNAEUs, 1758) & 1 & $\mathrm{E}$ \\
\hline Xanthorhoe spadicearia ([DENIS \& SCHIFF.], 1775) & 1 & $\mathrm{E}$ \\
\hline Cyclophora albiocellaria (HÜBNER, 1789) & 2 & Q \\
\hline Cyclophora punctaria (LiNNAEUS, 1758) & 2 & $\mathrm{~S}$ \\
\hline Scopula immorata (LINNAEUS, 1758) & 1 & $\mathrm{E}$ \\
\hline
\end{tabular}




\section{Melléklet (Folytatás)}

Appendix (Continued)

\begin{tabular}{|c|c|c|c|}
\hline \multirow[t]{3}{*}{ Sterrhinae } & Scopula ornata (SCOPOLI, 1763) & 1 & St \\
\hline & Scopula rubiginata (HuFNAGEL, 1767) & 1 & E-St \\
\hline & Timandra comae (A. SCHMIDT, 1931) & 1 & $\mathrm{E}$ \\
\hline \multicolumn{4}{|l|}{ Notodontidae } \\
\hline \multirow[t]{15}{*}{ Notodontinae } & Cerura vinula (LinNAEUs, 1758) & 1 & P-S \\
\hline & Clostera anastomosis (LINNAEUs, 1758) & 1 & $\mathrm{P}-\mathrm{S}$ \\
\hline & Clostera curtula (LinNAEUS, 1758) & 1 & $\mathrm{P}-\mathrm{S}$ \\
\hline & Clostera pigra (LINNAEUS, 1758) & 1 & $\mathrm{P}-\mathrm{S}$ \\
\hline & Euchila palpina (LINNAEUs, 1758) & 1 & E-er \\
\hline & Furcula bifida (BRAHM, 1787) & 1 & $\mathrm{P}-\mathrm{S}$ \\
\hline & Harpyia milhauseri (FABRICIUS, 1775) & 2 & $\mathrm{Q}$ \\
\hline & Notodonta dromedarius (LINNAEUS, 1758) & 2 & B-A \\
\hline & Phalera bucephala (LinNAEUS, 1758) & 1 & $\mathrm{P}-\mathrm{S}$ \\
\hline & Phalera bucephaloides (OCHSENHEIMER, 1810) & 2 & Pub \\
\hline & Pheosia tremula (CLERCK, 1759) & 1 & $\mathrm{P}-\mathrm{S}$ \\
\hline & Ptilodon capucina (LinNAEUs, 1758) & 1 & $\mathrm{~S}$ \\
\hline & Ptilodon cucullina ([DENIS \& SCHIFFERMÜLLER], 1775) & 1 & Nem \\
\hline & Stauropus fagi (LINNAEUS, 1758) & 1 & $\mathrm{~S}$ \\
\hline & Thaumetopoea processionea (LINNAEUS, 1758) & 2 & Q \\
\hline Endromidae & Endromis versicolora (LINNAEUS, 1758) & 3 & $\mathrm{~B}-\mathrm{A}$ \\
\hline \multicolumn{4}{|l|}{ Erebidae } \\
\hline \multirow[t]{6}{*}{ Lymantriinae } & Arctornis l-nigrum (MÜLLER, 1764) & 1 & Nem \\
\hline & Calliteara pudibunda (LINNAEUS, 1758) & 1 & Nem \\
\hline & Euproctis chrysorrhoea (LINNAEUS, 1758) & 1 & $\mathrm{~S}$ \\
\hline & Lymantria dispar (LINNAEUS, 1758) & 1 & $\mathrm{~S}$ \\
\hline & Lymantria monacha (LINNAEUS, 1758) & 1 & $\mathrm{Nem}$ \\
\hline & Ocneria rubea ([DENIS\&SCHIFFMÜLLER],1775) & 2 & Pub \\
\hline \multirow[t]{11}{*}{ Arctiinae } & Arctia caja (LiNNAEUS, 1758) & 1 & $\mathrm{E}$ \\
\hline & Diacrisia sannio (LINNAEUS, 1758) & 1 & Mezo \\
\hline & Euplagia quadripunctaria (PoDA, 1761) & 2 & Alto \\
\hline & Ocnogyna parasita (HÜBNER, 1790) & 2 & St-Rup \\
\hline & Phragmatobia fuliginosa (LiNNAEUs, 1758) & 1 & E \\
\hline & Rhyparia purpurata (LINNAEUS, 1758) & 1 & Mezo-H \\
\hline & Rhyparioides metelkana (LEDERER, 1861) & 1 & Helo \\
\hline & Spilosoma lubricipedum (LinNaEUs, 1758) & 1 & $\mathrm{E}$ \\
\hline & Spilosoma luteum (HUFNAGEL, 1767) & 1 & $\mathrm{E}$ \\
\hline & Tyria jacobaeae (LinNAEUS, 1758) & 2 & St \\
\hline & Watsonarctia deserta (BARTEL, 1902) & 2 & St-Rup \\
\hline \multirow[t]{2}{*}{ Lithosiinae } & Lithosia quadra (LINNAEUS, 1758) & 1 & ZE \\
\hline & Miltochrista miniata (FORSTER, 1771) & 1 & Nem \\
\hline \multirow[t]{2}{*}{ Catocalinae } & Catocala electa (BORKHAUSEN, 1792) & 1 & $\mathrm{P}-\mathrm{S}$ \\
\hline & Catocala elocata (ESPER, 1788) & 1 & $\mathrm{P}-\mathrm{S}$ \\
\hline
\end{tabular}




\section{Melléklet (Folytatás) \\ Appendix (Continued)}

\begin{tabular}{|c|c|c|c|}
\hline \multirow[t]{8}{*}{ Catocalinae } & Catocala fulminea (SCOPOLI, 1763) & 1 & $\mathrm{~S}$ \\
\hline & Catocala nupta (LiNNAEUs, 1767) & 1 & $\mathrm{P}-\mathrm{S}$ \\
\hline & Catocala promissa ([DENIS \& SCHIFFERMÜLLER], 1775) & 2 & $\mathrm{Q}$ \\
\hline & Catocala sponsa (LINNAEUs, 1767) & 2 & $\mathrm{Q}$ \\
\hline & Euclidia glyphica (LINNAEUS, 1758) & 1 & $\mathrm{E}$ \\
\hline & Gonospileia triquetra ([DENIS \& SCHIFF.], 1775) & 1 & St \\
\hline & Lygephila pastinum (TREITSCHKE, 1826) & 2 & Mezo-H \\
\hline & Minucia lunaris ([DENIS \& SCHIFFERMÜLLER], 1775) & 2 & Q \\
\hline Calpinae & Scoliopteryx libatrix (LINNAEUS, 1758) & 1 & $\mathrm{P}-\mathrm{S}$ \\
\hline \multirow[t]{2}{*}{ Hypeninae } & Hypena proboscidalis (LINNAEUS, 1758) & 1 & E-er \\
\hline & Hypena rostralis (LinNAEUS, 1758) & 1 & $\mathrm{E}$ \\
\hline Aventiinae & Laspeyria flexula ([DENIS \& SCHIFFERMÜLLER], 1775) & 1 & ZE \\
\hline \multirow[t]{2}{*}{ Phytometrinae } & Colobochyla salicalis ([DENIS \& SCHIFF.], 1775) & 1 & $\mathrm{P}-\mathrm{S}$ \\
\hline & Phytometra viridaria (CLERCK, 1759) & 1 & Mezo \\
\hline \multicolumn{4}{|l|}{ Nolidae } \\
\hline & Bena prasinana (LinNAEUs, 1758) & 1 & E-er \\
\hline \multicolumn{4}{|l|}{ Noctuidae } \\
\hline \multirow[t]{9}{*}{ Plusiinae } & Abrostola triplasia (LINNAEUS, 1758) & 1 & Alto \\
\hline & Autographa bractea ([DENIS \& SCHIFFERMÜLLER], 1775) & 1 & Alto \\
\hline & Autographa gamma (LiNNAEUS, 1758) & 1 & $\mathrm{~V}$ \\
\hline & Autographa pulchrina (HAWORTH, 1809) & 1 & Alto \\
\hline & Diachrysia chrysitis (LiNNAEUs, 1758) & 1 & Alto \\
\hline & Diachrysia chryson (ESPER, 1789) & 1 & Alto \\
\hline & Diachrysia zosimi (HÜBNER, 1822) & 4 & Hig \\
\hline & Macdunnoughia confusa (STEPHENS, 1850) & 1 & $\mathrm{E}$ \\
\hline & Plusia festucae (LINNAEUS, 1758) & 1 & Mezo-H \\
\hline \multirow[t]{4}{*}{ Acronictinae } & Acronicta aceris (LINNAEUS, 1758) & 2 & S \\
\hline & Acronicta auricoma ([DENIS \& SCHIFFERMÜLLER], 1775) & 3 & $\mathrm{~S}$ \\
\hline & Acronicta rumicis (LiNNAEUS, 1758) & 1 & $\mathrm{E}$ \\
\hline & Craniophora ligustri ([DENIS \& SCHIFFERMÜLLER], 1775) & 1 & $\mathrm{~S}$ \\
\hline \multirow[t]{12}{*}{ Xyleninae } & Actinotia polyodon (CLERCK, 1759) & 1 & Nem \\
\hline & Agrochola helvola (LinNAEUS, 1758) & 1 & $\mathrm{~S}$ \\
\hline & Amphipoea fucosa (FREYER, 1830) & 1 & Hig \\
\hline & Apamea monoglypha (HUFNAGEL, 1766) & 1 & $\mathrm{E}$ \\
\hline & Apamea sordens (HuFNAGEL, 1766) & 1 & Mezo \\
\hline & Charanyca trigrammica (HuFNAGEL, 1766) & 2 & St \\
\hline & Cosmia trapezina (LINNAEUS, 1758) & 1 & $\mathrm{~S}$ \\
\hline & Dypterygia scabriuscula (LINNAEUS, 1758) & 1 & E-er \\
\hline & Euplexia lucipara (LINNAEUS, 1758) & 1 & Alto-Nem \\
\hline & Gortyna flavago ([DENIS \& SCHIFFERMÜLLER], 1775) & 1 & Alto \\
\hline & Mesogona oxalina (HÜBNER, 1803) & 1 & Hel \\
\hline & Oligia strigilis (LINNAEUS, 1758) & 1 & $\mathrm{E}$ \\
\hline
\end{tabular}


Melléklet (Folytatás)

Appendix (Continued)

\begin{tabular}{|c|c|c|c|}
\hline \multirow[t]{7}{*}{ Xyleninae } & Phlogophora meticulosa (LinNAEUs, 1758) & 1 & $\mathrm{E}$ \\
\hline & Polymixis polymita (LINNAEUs, 1761) & 2 & Q \\
\hline & Rusina ferruginea (ESPER, 1785) & 1 & $\mathrm{~S}$ \\
\hline & Scotochrosta pulla ([DENIS \& SCHIFFERMÜLLER], 1775) & 2 & Pub \\
\hline & Trachea atriplicis (LINNAEUS, 1758) & 1 & $\mathrm{E}$ \\
\hline & Xanthia icteritia (HuFNAGEL, 1766) & 1 & $\mathrm{P}-\mathrm{S}$ \\
\hline & Xylena exsoleta (LinNAEus, 1758) & 1 & $\mathrm{~S}$ \\
\hline \multirow[t]{20}{*}{ Noctuinae } & Agrotis exclamationis (LinNAEUS, 1758) & 1 & $\mathrm{E}$ \\
\hline & Agrotis ipsilon (HuFNAGEL, 1766) & 0 & $\mathrm{E}$ \\
\hline & Agrotis segetum ([DENIS \& SCHIFFERMÜLLER], 1775) & 1 & $\mathrm{E}$ \\
\hline & Anaplectoides prasina ([DENIS \& SCHIFF.], 1775) & 1 & Alto \\
\hline & Axylia putris (LINNAEUS, 1761) & 2 & $\mathrm{E}$ \\
\hline & Cerastis leucographa ([DENIS \& SCHIFFERMÜLLER], 1775) & 1 & Nem \\
\hline & Cerastis rubricosa ([DENIS \& SCHIFFERMÜLLER], 1775) & 1 & Alto \\
\hline & Conistra rubiginosa (SCOPOLI, 1763$)$ & 2 & Q \\
\hline & Diarsia brunnea ([DENIS \& SCHIFFERMÜLLER], 1775) & 1 & Alto \\
\hline & Euxoa obelisca ([DENIS \& SCHIFFERMÜLLER], 1775) & 1 & St \\
\hline & Euxoa tritici (LINNAEUS, 1758) & 1 & St \\
\hline & Lycophotia porphyrea ([DENIS \& SCHIFFERMÜLLER], 1775) & 2 & $\mathrm{Fe}$ \\
\hline & Noctua fimbriata (SCHREBER, 1759) & 2 & $\mathrm{E}$ \\
\hline & Noctua janthina ([DENIS \& SCHIFFERMÜLLER], 1775) & 2 & $\mathrm{E}$ \\
\hline & Ochropleura plecta (LINNAEUS, 1761) & 1 & $\mathrm{E}$ \\
\hline & Xestia baja ([DENIS \& SCHIFFERMÜLLER], 1775) & 1 & Mezo \\
\hline & Xestia c-nigrum (LinNAEUS, 1758) & 1 & $\mathrm{E}$ \\
\hline & Xestia stigmatica (HÜBNER, 1813) & 1 & Mezo \\
\hline & Xestia triangulum (HuFNAGEL, 1766) & 2 & Mezo \\
\hline & Xestia xanthographa ([DENIS \& SCHIFFERMÜLLER], 1775) & 2 & Mezo \\
\hline Psaphidininae & Allophyes oxyacanthae (LINNAEUS, 1758) & 2 & $\mathrm{SzCs}$ \\
\hline \multirow[t]{14}{*}{ Hadeninae } & Cerapteryx graminis (LiNNAEUS, 1758) & 1 & Mezo \\
\hline & Dioszeghyana schmidtii (DiószeGHY, 1935) & 2 & $\mathrm{Q}$ \\
\hline & Hadena confusa (HuFNAGEL, 1766) & 1 & E-er \\
\hline & Hadena magnolii (BoISDUVAL, 1829) & 2 & Psz \\
\hline & Hadula trifolii (HuFNAGEL, 1766) & 1 & $\mathrm{E}$ \\
\hline & Lacanobia oleracea (LINNAEUS, 1758$)$ & 1 & $\mathrm{E}$ \\
\hline & Lacanobia suasa ([DENIS \& SCHIFFERMÜLLER], 1775) & 1 & E \\
\hline & Melanchra persicariae (LiNNAEUS, 1761) & 1 & Mezo \\
\hline & Melanchra pisi (LINNAEUS, 1758) & 1 & Alto \\
\hline & Mythimna albipuncta ([DENIS \& SCHIFFERMÜLLER], 1775) & 1 & Mezo \\
\hline & Mythimna conigera ([DENIS \& SCHIFFERMÜLLER], 1775) & 1 & Mezo \\
\hline & Mythimna l-album (LinNAEUS, 1758) & 1 & $\mathrm{E}$ \\
\hline & Mythimna pallens (LiNNAEUS, 1758) & 1 & $\mathrm{E}$ \\
\hline & Mythimna unipuncta (HAwORTH, 1809) & 0 & $\mathrm{~V}$ \\
\hline
\end{tabular}




\section{Melléklet (Folytatás) \\ Appendix (Continued)}

\begin{tabular}{|c|c|c|c|}
\hline \multirow[t]{6}{*}{ Hadeninae } & Orthosia cerasi (FABRICIUS, 1775) & 2 & Q \\
\hline & Orthosia cruda ([DENIS \& SCHIFFERMÜLLER], 1775) & 2 & Q \\
\hline & Orthosia gothica (LINNAEUS, 1758) & 1 & $\mathrm{~S}$ \\
\hline & Orthosia incerta (HuFNAGEL, 1766) & 1 & $\mathrm{~S}$ \\
\hline & Orthosia miniosa ([DENIS \& SCHIFFERMÜLLER], 1775) & 2 & Q \\
\hline & Tholera decimalis (PODA, 1761) & 1 & $\mathrm{E}$ \\
\hline \multirow[t]{2}{*}{ Cuculliinae } & Cucullia fraudatrix (EvERSMANN, 1837) & 1 & St \\
\hline & Cucullia umbratica (LINNAEUs, 1758) & 1 & $\mathrm{E}$ \\
\hline \multirow[t]{2}{*}{ Condicinae } & Eucarta amethystina (HÜBNER, 1803) & 5 & Hel \\
\hline & Eucarta virgo (TREITSCHKE, 1835) & 5 & Hel \\
\hline \multirow[t]{2}{*}{ Heliothinae } & Heliothis adaucta (BUTLER, 1878) & 1 & $\mathrm{~V}$ \\
\hline & Pyrrhia umbra (HufNAGEL, 1766) & 1 & Mezo \\
\hline \multicolumn{4}{|c|}{ Lasiocampidae } \\
\hline & Dendrolimus pini (LinNAEUS, 1758) & 1 & $\mathrm{Pi}$ \\
\hline & Eriogaster catax (LiNNAEUS, 1758) & 2 & $\mathrm{SzCs}$ \\
\hline & Eriogaster lanestris (LiNNAEUS, 1758) & 1 & S-Esz \\
\hline & Lasiocampa trifolii ([DENIS \& SCHIFFERMÜLLER], 1775) & 2 & St \\
\hline & Macrothylacia rubi (LINNAEUS, 1758) & 1 & $\mathrm{E}$ \\
\hline & Malacosoma neustrium (LINNAEUS, 1758) & 1 & E-er \\
\hline & Odonestis pruni (LINNAEUS, 1758) & 1 & S-Esz \\
\hline
\end{tabular}




\title{
Investigation of Macroheterocera fauna in Arló (Lepidoptera) \\ TAMÁS VITKÓ ${ }^{1}$ and GABRIELLA FINTHA ${ }^{2 *}$ \\ ${ }^{1}$ Nyírpalota út 25, H-1157 Budapest, Hungary \\ ${ }^{2}$ Eszterházy Károly University, Institute of Biology, Department of Botany and Plant Physiology, Leányka utca 6, H-3300 Eger, Hungary \\ *E-mail: fintha.gabriella@uni-eszterhazy.hu
}

ÁLLATTANI KÖZLEMÉNYEK (2021) 106(1-2): 000-000.

\begin{abstract}
The aim of this survey is to contribute to the better understanding of the presence and spread of Hungarian Macroheterocera species by collecting new data from the vicinity of Arló, an area which has been virtually unknown for moth-faunistical research. The area harbours a diverse mosaic habitat complex with good conditions for the local moths. In addition to the silvicolous and quercetalis species associated with the typical floral associations of the area, some wetland species also appear like Diachrysia zosimi. During the survey of an anthropogenic area affected by three different vegetation types, 206 moth species were identified. Out of these the occurrence of 21 protected species was confirmed. Important species of faunistical aspect of the area include: Acherontia atropos, Marumba quercus, Hyles livornica, Saturnia pyri, Phalera bucephaloides, Diachrysia chryson, Autographa bractea, Hadena magnolii, Hadena confusa, Scotochrosta pulla, Watsonarctia deserta, Cucullia fraudatrix, Eriogaster catax, E. lanestris, Dioszeghyana schmidtii.
\end{abstract}

Keywords: moth faunistics, protected area, diverse habitat complex, Northern Medium Mountains (Hungary), Carpathian Basin 